\title{
A new species of dwarf sea bass, genus Serranus (Serranidae: Actinopterygii), from the southwestern Atlantic Ocean
}

\author{
Alfredo Carvalho Filho ${ }^{1}$ and Carlos Eduardo Leite Ferreira ${ }^{2}$
}

Serranus aliceae n. sp. is described from Rio de Janeiro and Espírito Santo States, southeastern Brazilian coast. The species is readily distinguished from its congeners by the following combination of characters: scales around the caudal peduncle 20 or 21; total gill rakers on first branchial arch 23-29; cheek-scales rows 5 or 6 ; and by the coloration of live specimens, which are reddish with a broad, conspicuous, white stripe from post-orbital region to the caudal-fin base and a white abdomen. The new species apparently inhabits the deeper (30 or more meters) portions of reef environments along the subtropical Brazilian coast, and is possibly associated with upwelling cold-water masses. The species was observed hovering above rocky bottoms, feeding on micro-crustaceans, squid larvae, and zooplankton. This new species increases to eight the number of valid Serranus species recorded in the southwestern Atlantic.

Serranus aliceae sp. n. é descrita do Rio de Janeiro e Espírito Santo, costa sudeste do Brasil. Esta espécie é facilmente distinguível de suas congêneres pela seguinte combinação de caracteres: escamas ao redor do pedúnculo caudal 20 ou 21; rastros no primeiro arco branquial 23-29; 5 ou 6 séries de escamas na bochecha e pelo colorido de espécimes vivos, que têm corpo avermelhado com uma larga e evidente faixa branca que se estende da região pós-orbital à base da nadadeira caudal, e o ventre branco. A espécie nova aparentemente habita a parte profunda (30 metros ou mais) de ambientes recifais ao longo da costa subtropical brasileira, e possivelmente está associada a áreas de ressurgência. A espécie foi observada pairando acima de fundos rochosos, alimentando-se de microcrustáceos, larvas de lulas e zooplâncton. Esta espécie nova aumenta para oito o número de espécies válidas de Serranus registradas no Atlântico Sudoeste.

Key words: Brazil, Endemic species, Reef fish, Rocky reef, Subtropical, Teleostei.

\section{Introduction}

The "western Atlantic dwarf sea basses", as defined by Robins \& Ray (1986), comprise five genera of the Serranidae: Diplectrum, Hypoplectrus, Schultzea, Serranus and Serraniculus. A complete review of these genera is lacking despite the comprehensive work of Robins \& Starck (1961) and Meisler (1987) on the group. Twenty-nine species of Serranus are currently recognized, 21 of which inhabit the Atlantic Ocean. Thirteen species of the genus are recorded in the western Atlantic, nine of which have been reported in Brazilian waters (Roux, 1973; CarvalhoFilho, 1999; Heemstra et al., 2002; Moura \& Menezes, 2003; Heemstra, 2013): S. annularis (Gunther, 1880), S. atrobranchus (Cuvier, 1829), S. baldwini (Evermann \& Marsh, 1899), S. chionaraia Robins \& Starck, 1961, S. flaviventris (Cuvier, 1829), S. notospilus Longley, 1935, S. phoebe Poey, 1852, S. tabacarius (Valenciennes, 1829), and S. tigrinus (Bloch, 1790). There are no published records of $S$. chionaraia for Brazil, but the species was recently reported from Abrolhos Archipelago, Bahia (C. L. Sampaio, pers. comm.). Serranus notospilus Longley, 1935 and S. tigrinus (Bloch, 1790), reported by Roux (1973) and Carvalho-Filho (1999) as occurring in Brazil, are probably misidentifications. Serranus dewegeri Metzellar, 1919 is now included in Paralabrax (Robins \& Starck, 1961; Pondella et al., 2003), whereas Serranus auriga (Cuvier, 1829 ) is located in Dules (Robins \& Starck, 1961).

In March 2009, while scuba diving in Arraial do Cabo, Rio de Janeiro State, Brazil, the second author observed an unidentified, relatively small, perch-like fish at about 30 meters deep, hovering above the rocky bottom. This and three

\footnotetext{
${ }^{1}$ Fish Bizz Ltd. Rua Moncorvo Filho 51, 05424-070 São Paulo, SP, Brazil. alfie@telnet.com.br ${ }^{2}$ Laboratório de Ecologia e Conservação de Ambientes Recifais, Departamento de Biologia Marinha, Universidade Federal Fluminense. 24001-970 Niterói, RJ, Brazil. carlosferreira@id.uff.br
} 
other similar specimens were collected in that location. In December 2010, at a nearby site, the same author collected six additional specimens of that unidentified serranid, again at a depth of about $30 \mathrm{~m}$. In April and May 2012 six more specimens were collected on a depth of about $70 \mathrm{~m}$ in a reef about $40 \mathrm{~km}$ off the rio Doce mouth, in Espírito Santo State, Brazil. That species is described herein, on the basis of morphological evidence. With the addition of that species, eight valid Serranus are now confirmed to occur in Brazilian waters.

\section{Material and Methods}

Counts and measurements follow Robins \& Starck (1961). Standard Lengths are presented in $\mathrm{mm}$. In the description below, measurements are expressed as percentage of standard length (SL), except for the upper-jaw length, which is expressed as percentage of head length (HL). Meristic data are given in the description, followed by the frequency of each count in parenthesis and an asterisk indicating values for the holotype. Institutional abbreviations are: CIUFES, Coleção Ictiológica da Universidade Federal do Espírito Santo; MNRJ, Museu Nacional, Universidade Federal do Rio de Janeiro; MZUSP, Museu de Zoologia da Universidade de São Paulo; and ZUEC, Museu de História Natural da Universidade Estadual de Campinas. All specimens were collected with hand-nets while scuba diving.

\section{Results}

\section{Serranus aliceae, new species Figs. 1-2}

Holotype. MNRJ 38911, 67.1 mm SL, Brazil, Rio de Janeiro, Arraial do Cabo, Ilha de Cabo Frio, Saco dos Ingleses, 2300'25'S 4200'19”W, 30 m, 23 Dec 2010, C. E. L. Ferreira.

Paratypes. MNRJ 38912, 1, 45.1 mm SL; MZUSP 109159, 2, 34.9$60.3 \mathrm{~mm}$ SL; ZUEC 6354, 1, $53.5 \mathrm{~mm}$ SL, collected with holotype. MNRJ 38913, 2, 23.5-30.1 mm SL; ZUEC 6355, 1, 21.9 mm SL; ZUEC 6356, 1, $26.8 \mathrm{~mm}$ SL, Brazil, Rio de Janeiro, Arraial do Cabo, Ilha de Cabo Frio, Saco dos Ingleses, $23^{\circ} 00$ '25'S 42 00'19' W, 28 30 m, 29 Mar 2009, C. E. L. Ferreira. CIUFES 2368, 1, 40.3 mm SL; CIUFES 2370, 2, 30.4-35.6 mm SL, Brazil, Espírito Santo State, deep reef near Peroá-Linhares Petrobras oilrigs, $40 \mathrm{~km}$ off rio Doce mouth, 19³4'44”S 39¹7'19’'W, 70 m, 13-14 Apr 2012, T. E. Simon, H. T. Pinheiro, R. M. Macieira \& E.F. Mazzei.

Non-types. CIUFES 2382, 1, 33.4 mm SL, Brazil, Espírito Santo State, deep reef near Peroá-Linhares Petrobras oilrigs, $40 \mathrm{~km}$ off rio Doce mouth, 19³4'44’'S 39¹7'19’'W, 70 m, 13 Apr 2012, T. E. Simon, H. T. Pinheiro, R. M. Macieira \& E.F. Mazzei. CIUFES 2411, 2, 34.8-38.4 mm SL, Brazil, Espírito Santo State, deep reef near Peroá-Linhares Petrobras oilrigs, 40 km off rio Doce mouth, 19³4'44’'S 39¹7’19’W, 70 m, 29 May 2012, T. E. Simon, H. T. Pinheiro, R. M. Macieira \& E. F. Mazzei.

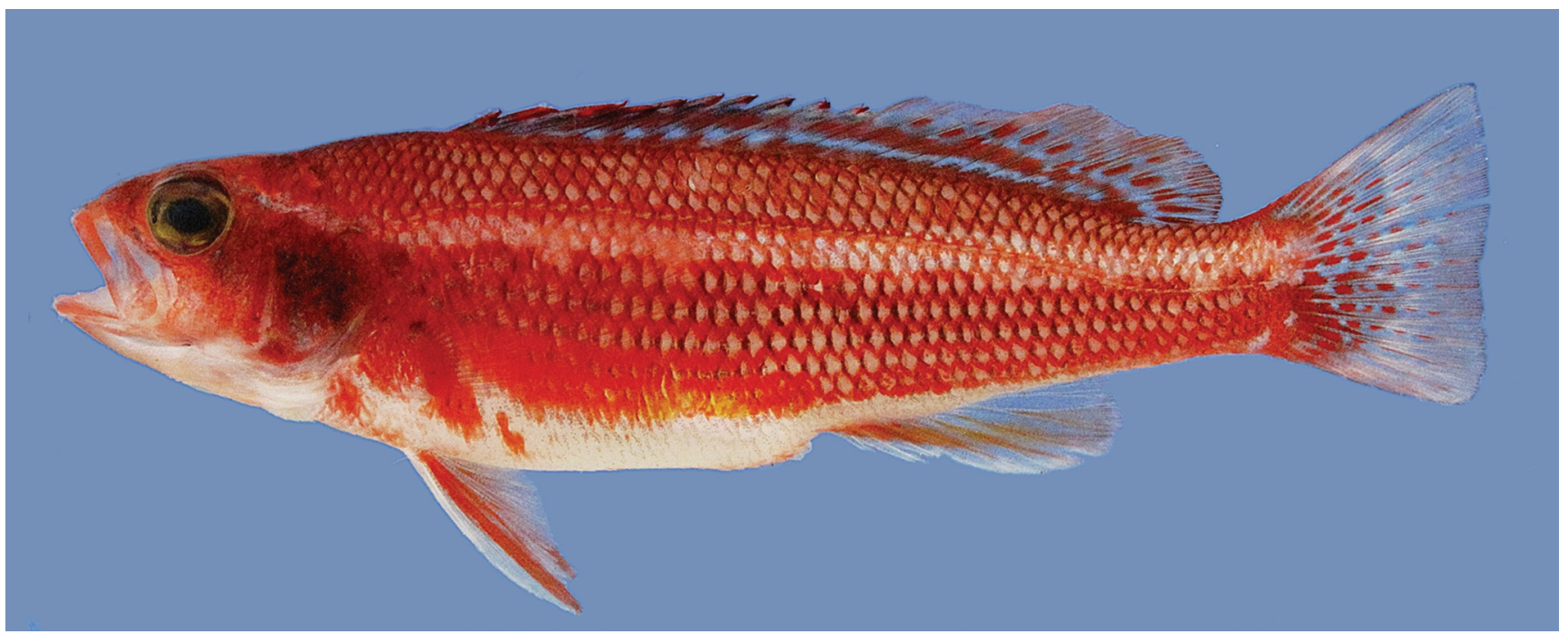

Fig. 1. Serranus aliceae, holotype, Brazil, Rio de Janeiro, Arraial do Cabo, Ilha de Cabo Frio, Saco dos Ingleses, MNRJ 38911, 67.1 mm SL, just after collection. Photo by Osmar J. Luiz. 

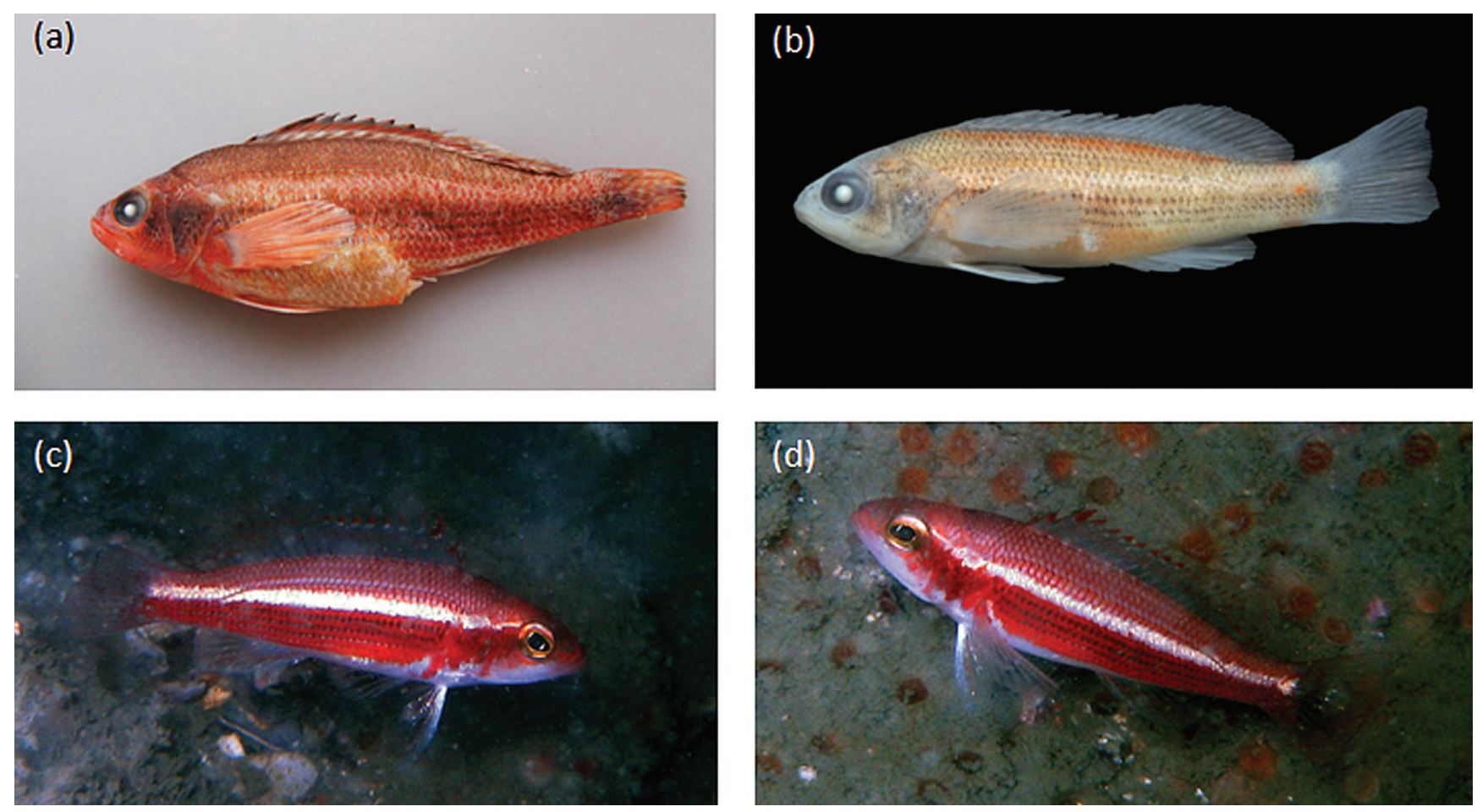

Fig. 2. Serranus aliceae: a) paratype, ZUEC 6354, $53.5 \mathrm{~mm} \mathrm{SL}$, recently fixed (photo by A. Carvalho-Filho); b) paratype, CIUFES 2368, $40.3 \mathrm{~mm}$ SL, after five days in ethanol (photo by R. M. Macieira); (c) and (d), underwater images at 35 (O. J. Luiz) and $40 \mathrm{~m}$ deep (C. E. L. Ferreira) on rocky reefs at Arraial do Cabo, Rio de Janeiro State, showing details of its live coloration.

Diagnosis. Serranus aliceae is readily distinguished from its congeners by the following combination of characters: scales around the caudal peduncle 20 or 21 ; total gill rakers on first branchial arch 23-29; cheek-scales rows 5 or 6 ; and by the coloration of live specimens, which are reddish with a broad, conspicuous, white stripe from post-orbital region to the caudal-fin base and a white abdomen. See Remarks for further comments on the diagnosis of the species.

Description. Measurements and counts are presented in Table 1. Body elongate, head sub-conical; inter-orbital region flattened. Mouth small, slightly oblique; maxilla almost reaching vertical through posterior margin of pupil, teeth in upper and lower jaws arranged in bands, a few outer ones enlarged and canine-like in both jaws of small specimens, adults with a few enlarged teeth only in lower jaw: a single teeth at symphysis and 1 or 2 laterally on each side; small villiform teeth on vomer and palatines; tongue lanceolate, proximal region very broad and distal tip bluntly pointed. Longest gill raker on first gill arch at angle, its size about half eye diameter. Nostrils in front of middle of eye and very close to one another, opening of anterior nostril about half the diameter of opening of posterior.

Opercle with three flat spines, the central straight, larger, and conspicuous than the others which are very difficult to see; opercular membrane pointed at posterior end. Preopercle profusely serrate on posterior border of vertical limb, with about 30 tiny spines plus 5-7 enlarged spines at angle, and smooth on horizontal, ventral, edge. Branchiostegal rays 7 .

Lateral line slightly arched over pectoral-fin area, parallel to dorsum profile from that point to the caudal peduncle, where it bends to middle of body and continues as a straight line to caudal-fin base. Scales ctenoid, firmly attached to skin, not deciduous; interorbital space, snout, preorbital region, jaws, dentary symphysis, gular region, and branchiostegal membranes naked; scales on top of head reaching anteriorly to vertical through posterior border of preopercle or slightly anterior to it; minute, embedded scales on basal half of soft portion of dorsal and anal fins; small scales only at the base of the pectoral fin.

Dorsal-fin origin over pectoral-fin base and fourth or fifth lateral-line scale; spiny portion incised; first spine about half length of second, third spine the longest, fourth to sixth somewhat shorter, seventh to tenth even shorter and subequal; dorsal-fin rays branched, last one branched to base; posterior tips of soft portion of dorsal and anal fins falls distinctly short of caudal-fin base when depressed. Anal-fin origin approximately below first dorsal-fin ray; first anal-fin spine about half the length of second, which is slightly shorter than third. Caudal fin truncate to slightly emarginated, the uppermost and lowermost caudal-fin rays not branched. Pectoral fin not reaching vertical through anus, all rays branched except uppermost and lowermost, eighth or ninth upper pectoral-fin ray longest. Pelvic-fin origin below pectoral-fin base, posterior tip not reaching anus. 
Color in life. Body golden reddish brown to light red with a conspicuous white stripe running from eye or upper portion of opercle to caudal-fin base (Fig. 1). Lower portion of body, from dentary symphysis to caudal-fin base milky white, often with large red area anterior to origin of pelvic fins. Dorsum with brassy shine, margin of scales dark. Lateral of body, between mid-lateral whitish band and white abdomen, with 3-5 lines of blue dots, sometimes followed ventrally by 1-3 whitish lines; blue-dotted lines often containing whitish scales among the darker ones; white lines sometimes containing some dark, bluish scales among the pale ones. A small, bright, golden area usually present in the abdomen under the pectoral fin and posterior to it. Several small blue dots on opercle and preopercle often merged. Dorsal fin with a dark red triangle at the tip of each spine, and two white stripes between series of red spots, the upper one beneath the upper row of spots and the lower one ventral to the second row of spots; the lower white stripe does not extend to the posterior end of the fin as the upper white stripe does. Caudal fin hyaline, with one to several reddish spots or blotches on each ray. Anal, pelvic, and pectoral fins with orange-reddish markings in adults: pectoral fin uniformly orange-reddish, pelvic and anal fins white anteriorly with orange-reddish pigment in inner twothirds; reddish orange pigment sometimes absent in small specimens. Upper portion of eye reddish to orange. When alive, $S$. aliceae is capable of changing the color pattern of its flanks, the white band fades dramatically and several conspicuous dark blotches between this band and the white belly are more apparent. Almost immediately after death, the blue dots on the ventrolateral portion of body usually disappear, remaining as an outline around scales, and the white band fades dramatically.

Color in alcohol. Body tan to brownish overall, ventral region whitish, the white lateral stripe barely discernible, faded to a tan tone lighter than background color; fins hyaline, sometimes with a suggestion of the reddish marks.

Etymology. The specific epithet aliceae refers to the name of the dear daughter of the second author, Alice. A noun in apposition.

Distribution. Specimens of $S$. aliceae were collected in two localities of southeastern Brazil: Arraial do Cabo, Rio de Janeiro State $\left(23^{\circ} 00^{\prime} 25^{\prime \prime} \mathrm{S} 42^{\circ} 00^{\prime} 19^{\prime \prime} \mathrm{W}\right)$, in a reef formation at about a depth of $30 \mathrm{~m}$, and also at about 40 miles off the rio Doce mouth, in Espírito Santo State, among reefs

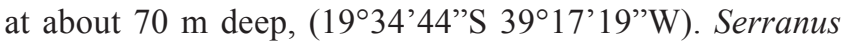
aliceae apparently inhabits the deeper (30 or more meters) portions of reef environments along the subtropical Brazilian coast, and is possibly associated with upwelling cold-water masses. It is the only species of Serranus known to date that is endemic to Brazil.
Remarks. Serranus aliceae has strongly ctenoid scales that are not deciduous, the top of head is not scaled in the region anterior to the posterior margin of the interorbital region, and the opercular spines are developed. That combination of characters places $S$. aliceae in the subgenus Serranus, as defined by Robins \& Starck (1961).

The low number of scales around the caudal peduncle (20 or 21) readily distinguishes $S$. aliceae from other Atlantic species of both the Serranus and Paracentropristis subgenera. Serranus atrobranchus (subgenus Paracentropristis), for instance, has 22-25 of such scales, whereas all other Atlantic species have 23 or more scales (Robins \& Starck 1961). Among the species of the subgenus Serranus reported from the western Atlantic, S. aliceae also differs in terms of coloration (images and descriptions of other species available in Humann \& DeLoach, 2002, and Kells \& Carpenter, 2011). Serranus aliceae is further distinguished from other Atlantic species of the genus by a series of features: $S$. annularis has a higher number of rows of scales on cheek (5 or $6 v s .10-12$ ). Serranus baldwini has a lower number of total gill rakers (2328 vs. 14-17). Serranus chionaria also has a lower number of gill rakers in the first branchial arch (23-28 vs. 17-20), in addition to a higher number of rows of scales on cheeks ( 5 or $6 v s .8$ or 9). The number of pectoral-fin rays is higher in $S$. flaviventris (14 or 15 vs. 16 or 17). Serranus luciopercanus has a higher number of cheek-scales rows (5 or $6 v s .8-10)$ and its middle opercular spine is upturned. Serranus phoebe has a lower number of total gill rakers (23-28 vs. 17-20) and a higher number of rows of scales on cheek (5 or 6 vs. 9-12). Serranus subligarius has a lower number of gill rakers in the first branchial arch (23-28 vs. 16 or 17). Serranus tabacarius has a higher number of lateral-line scales (46-48 vs. 50-55) and cheek-scales rows (5 or 6 vs. 10-12). Serranus tigrinus has a lower number of total gill rakers (23-28 vs. 15-19) and higher number of rows of scales on cheek (5 or $6 v s$. 11-13). Serranus tortugarum is the most similar species to $S$. aliceae in terms of counts, but differs by the longest dorsal fin spine ( $5^{\text {th }}$ in S. tortugarum vs. $3^{\text {rd }}$ in $S$. aliceae).

Serranus aliceae differs from the six Pacific species of the genus by the coloration pattern and several other features: from S. aequidens Gilbert, 1890, by the origin of the pelvic fins under the pectoral fin base ( $v s$. ahead of the pectoral fin base) and the length of the same fin (63-80\% in head length $v s$. about $50 \%$ ); from $S$. huascarii Steindachner, 1900 by the higher number of lower gill rakers (15-18 vs. 12 or 13) and the lower number of rows of scales on cheek (5 or 6 vs. 8-11); from $S$. psittacinus Valenciennes, 1846 by the lower number of scales around the caudal peduncle (20 or 21 vs. 24-30); from S. socorroensis Allen \& Robertson, 1992, by the lower number of scales around the caudal peduncle ( 20 or 21 vs. 27); from S. stilbostigma (Jordan \& Bollman, 1890) by the lower number of lateral-line scales 
(46-48 vs. about 58) (Gilbert, 1890; Jordan \& Eigenmann, 1890; Meisler, 1987; Allen \& Robertson, 1992; Allen \& Robertson, 1998; Heemstra, 1995; Bussing \& López, 2004; McCosker \& Rosenblatt, 2010). Although there was never a detailed formal description of S. tico Allen \& Robertson, 1998, from the Pacific Ocean, the species is currently considered as valid (e.g., Eschmeyer, 2013). Serranus aliceae differs from S. tico by the coloration pattern and geographical distribution. From the two western Indian Ocean Serranus species, S. knysnaensis Gilchrist, 1904 and S. novemcinctus Kner, 1865, Serranus aliceae differs by the coloration pattern and the lower number of lateral-line scales (46-48 vs. more than 67) (Heemstra \& Randall, 1986; Heemstra \& Heemstra, 2004).

Natural history. Serranus aliceae occurs in the deeper portion of coastal reefs, usually below $30 \mathrm{~m}$, and is often observed hovering at a short distance above rocks, sand or rubble (Fig. 2). Other species of the genus (e.g., S. tabacarius and S. tortugarum) also exhibit a similar hovering behaviour (Robins \& Starck, 1961; Randall, 1967). Pronotogrammus martinicensis (Guichenot, 1868), Dules auriga (Cuvier, 1829), and Chromis flavicauda (Günther, 1880) were occasionally observed in association with $S$. aliceae in the same site at Arraial do Cabo, Rio de Janeiro, Brazil. The stomach contents of four individuals of $S$. aliceae (ZUEC 6356, MNRJ 38912, MZUSP 109159, and the holotype MNRJ 38911) were examined. One of them had an empty stomach and intestine, the remainder had their stomachs and intestines almost full. Contents included carapaces of non-identified crustacean and a very tiny squid, which indicates that in addition to feeding on the bottom, S. aliceae is also a zooplankton picker. The four largest specimens examined have well-developed mature oocytes and sperm ducts, probably indicating that, like several other species of Serranus, they are simultaneous hermaphrodites (Erisman \& Hastings, 2011; Fischer \& Petersen, 1987). The largest fish examined with no mature oocytes or well developed sperm ducts is $34.9 \mathrm{~mm} \mathrm{SL}$, and the smallest one with well-developed mature oocytes and sperm ducts is $45.1 \mathrm{~mm} \mathrm{SL}$, suggesting that sexual maturity is attained at approximately $40 \mathrm{~mm}$ SL. Mass of two ripe individuals: holotype MNRJ 38911(67.1 mm SL), 4.44 $\mathrm{g}$, the eggs weighing $0.57 \mathrm{~g}$ ( $12.8 \%$ of total weight); paratype MZUSP 109159 (60.3 mm SL), $2.94 \mathrm{~g}$, the eggs weighing 0.30 $\mathrm{g}(10.2 \%$ of total weight $)$.

Conservation status: Serranus aliceae is the smallest species of the genus reported for the Brazilian coast, making it difficult to capture by commonly used commercial and/or artisanal fishing gears. Only S. phoebe and S. atrobranchus were previously identified from fish larvae collections made along the subtropical coast (Figueiredo et al., 2002). Like those species, $S$. aliceae is probably distributed along the subtropical Brazilian coast, where the South Atlantic Central Water (SACW, $\mathrm{T}<18^{\circ} \mathrm{C}$ ) influences coastal reefs
(Castro-Filho \& Miranda, 1998). Deep-reef exploration is resulting in the discovery of new endemic species (Luiz et al., 2009) and distinct populations of widespread species (Carvalho-Filho et al., 2009), underscoring this habitat as an important biodiversity repository. As all but the upper portions of deep reefs are beyond the maximum depths reached with traditional SCUBA gear, specialized skills and equipment are required (Pyle, 2000). Subtropical deep reefs and associated assemblages of the southern and southeastern Brazilian coast may not be under threat by impacts that are traditionally associated with shallow reefs (e.g., anthropogenic plus climate effects), but they may be impacted by different fishing practices. Major stresses, if any, on fishes inhabiting mesophotic cold reefs in the subtropical Brazilian coast are yet unknown. We suggest that deep-reef cryptic fishes like the small S. aliceae should be categorized as Data Deficient (DD) according to the IUCN (International Union for Conservation of Nature) criteria in future conservation assessments, pending more research on Brazilian deep-reef systems.

Comparative material. Serranus atrobranchus, MZUSP 55435, 1, 96.3 mm SL, Brazil, Santa Catarina, Florianópolis, Ilha do Arvoredo. S. baldwini, MZUSP 65593, 1, $53.2 \mathrm{~mm}$ SL, Brazil, Pernambuco, Tamandaré, Recife Carapitanga. MZUSP 53117, 1, 44.2 mm SL, Brazil, Maranhão, Parcel Manoel Luis. S. flaviventris, MZUSP 79742, 4, 54.3-62.1 mm SL, Brazil, Espírito Santo, Guarapari, Três Ilhas. MZUSP 60790, 4, 41.4-53.1 mm SL, Brazil, Bahia, Arquipélago de Abrolhos, Recife Popa Verde. S. phoebe, MZUSP 71073, 2, 158.3-172.6 mm SL, Brazil, São Paulo, Ubatuba.

\section{Acknowledgments}

The authors are grateful to Carole Baldwin and D. Ross Robertson (NMNH), José Lima Figueiredo and Naércio A. Menezes (MZUSP), Osmar J. Luiz (Macquarie University), Luiz Rocha (CAS), Ivan Sazima (ZUEC), and an anonymous reviewer for their support, advice and for reviewing the manuscript; Osmar J. Luiz and Raphael M. Macieira (UFES) for their fine pictures; T. E. Simon, H. T. Pinheiro, R. M. Macieira and E. F. Mazzei (UFES) for sending data about the presence of the species at Espírito Santo deep-reef waters; Jean C. Joyeux (UFES) for sending us the Espírito Santo specimens. The second author is supported by grants from CNPq and FAPERJ.

\section{Literature Cited}

Allen, G. R. \& D. R. Robertson. 1992. Serranus socorroensis, a new species of serranid fish from the Tropical Eastern Pacific Ocean. Revue Française d'Aquariologie, 19: 37-40.

Allen, G. R. \& D. R. Robertson. 1998. Peces del Pacífico Oriental tropical. Comisión para el Conocimiento y Uso de la Biodivesidad y Agrupación Sierra Madre, S. C. Ciudad de México. 
Bussing, W. A. \& M. I. López. 2004. Peces de Isla del Coco y peces arrecifales de la costa pacifica de Centro America Meridional, guia ilustrado. Revista de Biologia Tropical, 52: Suppl. 3, 1-171.

Carvalho-Filho, A. 1999. Peixes, costa brasileira. $3^{\text {rd }}$ Ed. Melro, São Paulo.

Carvalho-Filho, A., C. E. L. Ferreira \& M. Craig. 2009. A shallow water population of Pronotogrammus martinicensis (Guichenot, 1868) (Teleostei: Serranidae: Anthiinae) from South Western Atlantic, Brazil. Zootaxa, 2228: 29-42.

Castro-Filho, B. M. \& L. B. Miranda. 1998. Physical oceanography of the western Atlantic continental shelf 1 ocated between $4^{\circ} \mathrm{N}$ and $34^{\circ} \mathrm{S}$ costal segment (4'W). Pp. 209-251. In: Robinson, A. R. \& K. H. Brink, The Sea. John Wiley \& Sons, Oxford.

Erisman, B. E. \& P. A. Hastings. 2011. Evolutionary Transitions in the Sexual Patterns of Fishes: Insights from a Phylogenetic Analysis of the Seabasses (Teleostei: Serranidae). Copeia, 2011: 357-364.

Eschmeyer, W. N. (Ed.). 2013. Catalog of Fishes. California Academy of Sciences. Electronic version updated 15 Nov 2013. Available from: http://research.calacademy.org/research/ichthyology/cata$\log$ /fishcatmain.asp. (October 2013).

Figueiredo, J. L., A. Santos, N. Yamaguti, R. A. Bernardes \& C. L. B. Rossi-Wongtschowski. 2002. Peixes da Zona Econômica Exclusiva da Região Sudeste-Sul do Brasil: levantamento com rede de meia água. EDUSP, São Paulo.

Fischer, E. A. \& C. W. Petersen. 1987. The evolution of sexual patterns in the seabasses. BioScience, 37: 482-489.

Gilbert, C. H. 1890. A preliminary report on the fishes collected by the steamer Albatross on the Pacific coast of North America during the year 1889, with descriptions of twelve new genera and ninety two new species. Proceedings United States National Museum, 13: 49-126.

Heemstra, P. C. 1995. Serranidae. In: Fischer, W., F. Krupp, W. Schneider, C. Sommer, K. E. Carpenter \& V. H. Niem (Eds.). Guia FAO para la identificación de especies para los fines de la pesca. Pacifico Centro-Oriental. Vol III, Vertebrados, Parte 2. Rome.

Heemstra, P. C. 2013. Serranidae. In: Froese, R. \& D. Pauly (Eds.). Fishbase. World Wide Web Electronic Publication. Available from: http//www.fishbase.org, version October 2013. (12 Dec 2013)

Heemstra, P. C., W. D. Anderson, Jr. \& P. S. Lobel. 2002. Serranidae. Pp. 1308-1369. In: Carpenter, K. E. (Ed.). The Living Marine Resources of the Western Central Atlantic, FAO, Rome. Bony fishes part 1 (Acipenseridae to Grammatidae).

Heemstra, P. C. \& E. Heemstra, 2004. Coastal Fishes of Southern Africa. National Inquiry Service Centre and South African Institute for Aquatic Biodiversity (SAIAB). Grahamstown.

Heemstra, P. C. \& J. E. Randall. 1986. Serranidae. Pp. 536-537. In: Smith, M. M. \& P. C. Heemstra (Eds.). Smiths' sea fishes. Springer-Verlag, Berlin.
Humann, P. \& N. DeLoach. 2002. Reef Fish Identification - Florida, Caribbean, Bahamas, $3^{\text {rd }}$ Ed. New World Publications Inc., Jacksonville, Florida.

Jordan, D. S. \& C. H. Eigenmann. 1890. A review of the genera and species of Serranidae found in the waters of America and Europe. Bulletin United States Fish Commission, 8: 329-441.

Kells, V. \& K. Carpenter. 2011. A Field Guide to Coastal Fishes from Maine to Texas. The Johns Hopkins University Press, Baltimore.

Luiz, Jr., O. J., C. E. L. Ferreira \& L. A. Rocha. 2009. Halichoeres sazimai, a new species of wrasse (Perciformes: Labridae) from the Western South Atlantic. Zootaxa, 2092: 37-46.

McCosker, J. E. \& R. H. Rosenblatt. 2010. The Fishes of the Galapagos Archipelago: An Update. Proceedings of the California Academy of Sciences, 11: 167-195.

Meisler, M. R. 1987. Limits and Relationships of Serraninae Seabasses, with revisions of Serranus and Mentiperca (Pisces: Serranidae). Unpublished Ph.D. Dissertation, University of Southern California.

Moura, R. L. \& N. A. Menezes. 2003. Serranidae. In: Menezes, N. A., P. A. Buckup, J. L. Figueiredo \& R. L. Moura (Eds.). Catálogo das Espécies de Peixes Marinhos do Brasil. Museu de Zoologia da Universidade de São Paulo, São Paulo.

Pondella II, D. J., M. T. Craig \& J. P. C. Franck. 2003. The phylogeny of Paralabrax (Perciformes: Serranidae) and allied taxa inferred from partial 16S and 12S mitochondrial ribosomal DNA sequences. Molecular Phylogenetics and Evolution, 29: 176-184.

Pyle, R. L. 2000. Assessing Undiscovered Fish Biodiversity on Deep Coral Reefs Using Advanced Self-Contained Diving Technology. Marine Technology Society Journal, 34: 82-91.

Randall, J. E. 1967. Food habits of reef fishes of West Indies. Studies in Tropical Oceanography, 5: 665-847.

Robins, C. R. \& W. A. Starck, II. 1961. Materials for a Revision of Serranus and related genera. Proceedings of the Academy of Natural Sciences of Philadelphia, 113: 259-314.

Robins, C. R. \& G. C. Ray. 1986. A field guide to Atlantic coast fishes, North America. Houghton Mifflin, Boston.

Roux, C. 1973. Poissons Téléostéens du Plateau Continental Brésilien. Campagne de la Calypso au large des cotes atlantiques de L'Amerique du Sud (1961-1962), Prémiere Parte (suite). Resultats Scientifiques dês Campagnes de La Calypso, X. Annales de L'Institut Océanographique, Nouvelle Série, 49, Fascicule Supplémentaire. Maison et Cie, Editeurs, Paris.

Submitted January 19, 2013

Accepted October 26, 2013 by Fabio Di Dario

Published December 27, 2013 